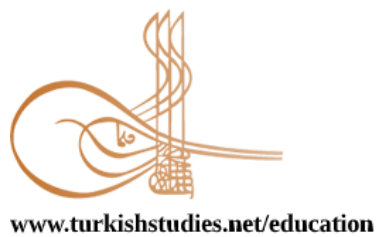

Turkish Studies - Educational Sciences

\title{
Ortaokul Türkçe Dersi Öğretim Programının Yazma Öğrenme Alanı Bağlamında Değerlendirilmesi ve Programda Planlama ve Yazma Stratejilerinin Yerinin Belirlenmesi
}

\author{
Evaluation of Elementary School Turkish Lesson Curriculum in the Context of the Field of \\ Learning Writing and Determination of the Place of Planning and Writing Strategies in the \\ Curriculum
}

\author{
Eylem Ezgi Özdemir ${ }^{*}$ Nevin Akkaya**
}

\begin{abstract}
The process of development and implementation of a curriculum is dependent upon the recommendation provided as a result of the scientific research in the literature. Therefore, this study aims to evaluate elementary school Turkish Lesson Curriculum (TLC) which was published by the Board of Education and Discipline in 2018 and updated in 2019, to determine the place of planning and writing strategies in the said curriculum, and to bring forth certain recommendations for the implementation of the curriculum. For this purpose, the study was devised as a qualitative case study and the related data were obtained by document analysis as a qualitative research technique. Upon examination of 2019 TLC learning outcomes for the field of learning writing, 58 outcomes in total (27 main outcomes and 31 sub-outcomes linked to the main outcomes) were identified in the fifth, sixth, seventh, and eighth grade levels. These learning outcomes are divided into four categories as follows: learning outcomes for text genre knowledge, learning outcomes for writing process, learning outcomes for grammar, and learning outcomes for supporting content of the text. A specific review of the category of planning and writing strategies revealed that "strategy" word was merely included as a term in each of the class. In addition, for each grade, the learning outcome "Implements writing strategies" was detected, which indicated no strategy use whatsoever. Moreover, it was found that "planning" stage before writing was not directly included as a learning outcome among others. Based on the findings of the research, it was concluded that comprehensiveness of learning outcomes included in 2019 TLC should be increased in terms of developing writing skill by adding more detail to the field of learning writing, and the curriculum should be enriched with sufficient learning outcomes for strategy teaching.
\end{abstract}

\section{Structured Abstract}

The process of development and implementation of a curriculum must be based on the various recommendations made by the results of the scientific research in the literature. The instructional process is of quality so long as the curricula that offer a framework for the teaching process and content include contemporary and competent features. Educational programs are devised or entirely renewed for various

\footnotetext{
${ }^{*}$ Arş. Gör., Balıkesir Üniversitesi, Necatibey Eğitim Fakültesi Türkçe Eğitimi Bölümü ABD Res.Ass., Ballkesir University, Necatibey Education Faculty, Turkish Education Department. ORCID 0000-0003-4471-8228 
reasons such as to meet the needs of the time, to fill the gaps of the pre-existing curriculum, and to put new improvements in the education field into practice. In line with this, this research dealt with the learning outcomes for learning writing in 2019 Turkish Language Curriculum (TLC) renewed in accordance with the necessities of the time and attempted to determine the place of planning and writing within these learning outcomes. The research was conducted as a qualitative case study. The data was collected through document review. As for the main document, learning outcomes for the writing skill that was included as a learning field in TLC were reviewed and the findings regarding these outcomes were reported through an evaluation. Outcomes reviewed in the research were limited to the learning outcomes for learning writing field in the grade levels of five, six, seven, and eight. In the research, the data retrieved by means of document analysis method were analyzed with content analysis technique. Initially, outcomes in the fifth, sixth, seventh, and eighth grade levels in 2019 TLC were determined through reviewing and were listed. Subsequently, the outcomes included in the fifth, sixth, seventh, and eighth grade levels in 2019 TLC were divided into four categories to be reviewed in terms of the involvement of planning and writing strategies in these outcomes as follows: outcomes regarding the knowledge of text genre, outcomes regarding the writing process, outcomes regarding grammar, and outcomes regarding supporting the content of the text. In the study, firstly, it was deducted that outcomes in the field of writing were not adequately detailed both in a general sense and separately for each grade level. Secondly, it was found that even though some outcomes in the curriculum shared similar target behavior, they were phrased with distinct outcome statements. Thirdly, it was observed that there were only a few outcomes regarding the spelling rules in the curriculum, not involving any explanations for the corresponding outcomes whatsoever. Fourthly, when the curriculum was evaluated in the sense of text genre, it was detected that the curriculum benefitted from three genres, which were narrative and informative texts and poems, that genre types were limited to these three genres, and that the most frequent explanations were made for the narrative texts. Fifthly, from the perspective of planning and writing strategies, it was observed that only the "strategy" word was involved as a concept in each grade level concerning planning and writing strategies. In addition, planning in writing education was not mentioned in the curriculum, nor any learning outcomes were included regarding planning strategies. Even though outcomes toward revising and sharing the written work, writing an appropriate title, using suitable cohesion and linking statements, and employing writing strategies are regarded as outcomes for revision of the written work as the most important stage of writing, considering the content of the sub-outcomes, it was found that it included a grammar learning outcome. In other words, the related suboutcomes are grammar topic learning outcomes despite aiming to regulate the writing in various ways. Revision stage is a significant phase in writing process, and therefore, there should be learning outcomes regarding regulating the writing process under this outcome instead of grammar. Regulation of these outcomes in the curriculum in the light of these findings might be recommended. In the curriculum, outcomes "Finds a content appropriate title for the written work" and "Uses suitable cohesion and linking statements in the written work" might be interpreted as outcomes indicating planning and writing strategies at first glance. However, these outcomes in the writing skill-oriented curriculum did not directly focus on strategy use, the word "strategy" did not convey a usage to serve the purpose, and this word was only used as a mere term in the learning outcomes. It can be stated that strategy use was regarded as activity-based in the curriculum; permanence of strategy use was not mentioned; and the curriculum was not equipped to teach writing strategies and to support strategy use in the writing process. Therefore, as a consequence, Turkish teachers need to gain awareness to employ writing strategies consciously and to teach the strategies. This necessity can be actualized via a strategic language teaching and a strategic instruction of all basic language skills. As this instruction is given with the certain curricula, it is crucial to provide a wide range of suggestions regarding the program. In native language teaching, utilizing strategies in teaching process particular to writing skills and in writing activities will be beneficial for both teachers and students in the writing process. That is why, Turkish language pre-service teachers' knowledge about strategy use must be developed in undergraduate writing education lesson and activities must be devised for the process of employing the strategies. Additionally, teachers must be provided with various in-service trainings to increase their knowledge about strategy use, encouraging them to allocate more time for practice in their classrooms. As for the future research that will take place in the literature, it can be recommended that comparative studies be conducted in the light of the pre-existing 2019 TLC compared to previous or future versions. This study was limited to writing as a learning field and, as for grade level, to the

Turkish Studies - Education, 15(3) 
fifth, sixth, seventh, and eighth grades. Thusly, future research might handle all learning areas and grade levels in a more detailed manner. Moreover, more comprehensive results can be reached with quantitative data gathered through more standard measurement tools.

Keywords: Turkish education, curriculum, 2019 TLC, writing, planning and writing strategies.

Öz: Bir öğretim programının geliştirilme ve uygulanma süreci, alanyazında var olan bilimsel çalışmaların sonuçları ile getirilen çeşitli önerilere dayalı olarak gerçekleştirilmelidir. Bu nedenle bu araştırmada, Talim Terbiye Kurulu tarafından 2018 yılında yayınlanan ve 2019 yilında güncellenen ortaokul Türkçe dersi öğretim programını yazma öğrenme alanı bağlamında değerlendirmek, planlama ve yazma stratejilerinin programdaki yerini belirlemek ve programın uygulanma sürecine ilişkin çeşitli öneriler sunmak amaçlanmıştır. Bu amaçla araştırma, nitel durum araştırması olarak tasarlanmış ve veriler doküman incelemesi yoluyla elde edilmiştir. Araştırmanın sonunda, 2019 TDÖP'te bulunan yazma öğrenme alanı kazanımlarına bakıldığında beşinci, altıncı, yedinci ve sekizinci sınıf düzeyinde toplamda 58 kazanımın yer aldığı (27 ana kazanım ve bu kazanımlara bağlı 31 alt kazanım) belirlenmiştir. Bu kazanımlar; metin tür bilgisine yönelik kazanımlar, yazma sürecine ilişkin kazanımlar, dil bilgisine yönelik kazanımlar ve metnin içeriğini desteklemeye yönelik kazanımlar olarak dört kategoriye ayrılarak incelenmiştir. Planlama ve yazma stratejileri özelinde incelendiğinde sınıfların her birinde "strateji” sözcüğünün yalnızca bir terim olarak yer aldığı görülmüş ve her sınıf düzeyinde yalnızca bir "Yazma stratejilerini uygular." kazanımının olduğu ve bu kazanımın strateji kullanıma işaret etmediği bulgulanmıştır. Ayrıca bu kazanımlar içinde yazma öncesi "planlama" aşamasına ilişkin kazanımın doğrudan yer almadığı belirlenmiştir. Araştırmanın bulgularından hareketle, 2019 TDÖP’ün yazma öğrenme alanı açısından daha fazla ayrıntılandırılarak programda yer alan kazanımların yazma becerisini geliştirmeye yönelik olarak kapsayıcılığının arttırılması gerektiği ve programın strateji öğretimine yönelik yeterli kazanımlar ile de zenginleştirilmesi gerektiği sonucuna ulaşılmıştır.

Anahtar Kelimeler: Türkçe eğitimi, öğretim programı, 2019 TDÖP, yazma, planlama ve yazma stratejileri.

\section{Giriş}

Öğretim programlarının geliştirilmesi ve kullanıma uygun biçime getirilmesi, eğitimöğretim sürecinin planlanması ve yapılandırılması açısından önemli bir adımdır. Öğretim programları, eğitim-öğretim sürecinin planlanmasında kılavuzluk eden en önemli araçlardan biridir. Öğrencilerin hedef kazanımlara erişisini sağlamak ve hedef davranışlarda gelişimlerini sürdürmek öğretim programlarının temel amaçlarındandır. $\mathrm{Bu}$ doğrultuda öğretim programlarının genel amaçları incelendiğinde, en genel amacının temel dil becerilerinin bütün öğrencilere istendik düzeyde kazandırmak olduğu görülür (Guthrie, Wigfield, Barbosa, Perencevich, Taboada, Davis, Scaffidi ve Tonks, 2004).

Anadili eğitimi özelinde Türkçe dersi öğretim programında sistematik bir yapı içerisinde dört temel dil becerisinin istendik düzeyde kazandırılması amaçlanır. Bir öğretim programı, hedeflediği alanda, hedeflediği becerilerin kazandırılmasında etkin bir öngörüyle çağın gereklerine uygun olarak yapılandırılır. Süreç içinde çeşitli gereksinimler doğrultusunda ilgili öğretim programı güncellenebilir. Bu amaçla, Talim Terbiye Kurulu tarafından 2018 yılında, önceki (TDÖP) Türkçe dersi öğretim programı (2015) düzenlenerek yeni bir program yayımlanmıştır. Bu program daha sonra 2019 yılında yeniden güncellenmiş ve Türkçe dersi öğretim programı olarak kullanıma sunulmuştur. 2019 TDÖP'te diğer programlardan (2006, 2015 ve 2018 TDÖP) farklı olarak öğretim programının yansıması olarak değerler ve yetkinlikler tanımlanmış, programın genel amaçları belirtilerek öğrenme alanları üçten dörde çıkarılmıştır (Bkz: 2015 TDÖP). Programda, "Dinleme/İzleme, Konuşma, Okuma (Akıcı Okuma, Sözvarlığı ve Anlama) ve Yazma" öğrenme alanları ile bu dört öğrenme alanına ilişkin kazanımlara yer verildiği ancak bu kazanımların 2006 TDÖP'teki gibi ayrıntılandırılmadığı belirlenmiştir. Ayrıca, 2019 Avrupa Yeterlikler Çerçevesine (AYÇ) uygun olarak ülkemiz öğretim programları için 2019 Türkiye Yeterlikler Çerçevesi (TYÇ) becerileri programa eklenmiştir. Bu gelişmeler ışığında bu araştırmada yazma öğrenme alanının programda yer alış biçimini irdelenecek ve özelde planlama ve yazma stratejilerinin yerini 
belirlenecektir. Araştırma sonunda yapılacak öneriler araştırmacılara ve uygulayacılara katkı sağlayacaktır.

Yaşamsal bir beceri olan yazma becerisinin eğitim-öğretim sürecinde öğrencilere kazandırılması ve geliştirilmesi oldukça önemlidir. $\mathrm{Bu}$ nedenle örgün öğretimin hemen tüm basamaklarında da yazma ediminin kazandırılması ve yazma becerisinin geliştirilmesine ilişkin öğretim programlarında kazanımlar yer alır ve bu kazanımlara erişi sağlayabilmek için ders kitaplarında çeşitli etkinlikler bulunur. Öğrencilerin yazılı anlatım becerilerinin geliştirilmesi Türkçe ögretiminin temel amaçlarından biri olarak 2019 TDÖP'te yer alır. 2019 TDÖP'te eğitim sisteminin yetkinliklerde bütünleşmiş bilgi, beceri ve davranışlarla donanımlı bir karakterde bireyler yetiştirmenin amaçlandığ1 vurgulanır. Programda öğrencilerin gereksinim duyacakları beceri yelpazeleri olan sekiz anahtar yetkinlik "2019 Türkiye Yeterlilikler Çerçevesi” nde (TYÇ) belirlenmiştir. TYÇ'de yer alan ilk yetkinlik ise "anadilinde iletişim"dir. Anadilinde iletişim; kavram, düşünce, görüş, duygu ve olguları hem sözlü hem de yazılı olarak ifade etme ve yorumlama (dinleme, konuşma, okuma ve yazma); eğitim ve öğretim, iş yeri, ev ve eğlence gibi her türlü sosyal ve kültürel bağlamda uygun ve yaratıcı bir biçimde dilsel etkileşimde bulunma olarak tanımlanmıştır. TYÇ'ye alınan bu yetkinlerden ilki ve en önemlisinin anadilinde iletişim yetkinliği olması, dil becerilerinin bireyin anlam evrenine yaptığı katkı ile gündelik yaşamdaki kazanımlarına ilişkin farkındalık sağlama adına önemlidir.

Öğretim süreci ve içeriği için bir çerçeve sunan öğretim programları, çağdaş ve yetkin özelliklere yer verdiği ölçüde öğretim süreci nitelikli biçime gelir (Ar1 ve Keskin, 2016) ve eğitimöğretim programları çağın gerektirdiği gereksinimleri karşılamak, kullanılmakta olan programın eksikliklerini gidermek, eğitim alanındaki yeni gelişmeleri uygulamaya aktarmak gibi çeşitli amaçlarla düzenlenir ya da bütünüyle yenilenir (Durukan, 2013). Bu araştırmada da, çağın gereklerine uygun olarak yenilenen 2019 TDÖP'te yazma öğrenme alanındaki kazanımlar ele alınarak programın bir değerlendirilmesi yapılmış ve bu kazanımlar içinde planlama ve yazma stratejilerinin yerinin belirlenmesi amaçlanmıştır. Bu amaçla, araştırmanın sonunda hem öğretim programını hazırlayıcılara geribildirim sağlamak için hem de bu öğretim programını derslerinde kullanan Türkçe öğretmenlerine katkı sağlayacak çeşitli önerilerin sunulabileceği düşünülmektedir.

\section{Planlama ve Yazma Stratejileri}

Yazma, bireyin kendini doğru ve amacına uygun olarak ifade etmesinde ve iletişim kurmasında en etkili araçlardan biridir (MEB, 2006). Bir süreç gerektiren yazma, yazma öncesi hazırlık, taslak oluşturma, düzenleme, gözden geçirme ve yayımlama aşamalarından (Tompkins, 2000) oluşan aşamalı bir süreçtir. Güneş (2007), yazma sürecini yazma öncesi aşama, yazma aşaması ve yazma sonrası aşama olarak ele alır ve yazma öncesinde zihinsel hazırlık ve zihinsel tasarım süreçleri tamamlandıktan sonra yazma aşamasına geçilmesi gerektiğini vurgular.Yazma, aklımıza geleni gelişigüzel sıraladığımız bir etkinlik değildir. Düşüncelerimizi planlayacağımız ve düzenleyebileceğimiz bir yöntem gerektirir (İpşiroğlu, 1993). Başarılı bir yazma süreci için buluş (duygu ve düşünce üretme), düzenleyiş (plan yapma) ve anlatış (ifade etme) olarak üç temel ilkenin göz önünde bulundurulması gerekir (Kavcar, Oğuzkan ve Aksoy, 2012). Yazma süreci gibi planlama süreci de aşamalı olarak yapılandırılır. Özdemir ve Binyazar (2006), plan yapmanın düşüncelerimizi denetlemeyi ve aralarındaki bağlantıya göre sıralama ve biçimlendirmeyi sağlamak için düşüncelerin dökümü, düşüncelerin ayrılması ve düşüncelerin kümelendirilmesi olarak üç aşamadan oluştuğunu belirtir. Plan, bir yazıda öne sürülecek bilgi ve düşüncelerin ilgi ve önem derecesine göre sıralanarak aktarılmasıdır. Yazıya aktarılmak istenen düşüncelerin kurgusunun oluşturulduğu planlama süreci, düşünce üretme, amaç belirleme, düşünceleri düzenleme ve sıralama gibi bir dizi alt süreci kapsayan yazının ilk adımını oluşturan önemli bir süreçtir. Planlama sürecine ayrılan süre ve sürenin verimliliği genel olarak yazma sürecinin rahat geçmesine katkı sağlarken ortaya çıkacak olan yazma 
ürünün niteliğini artırır. Bu nedenle yazma stratejileri kadar yazma öncesi planlama startejilerinin de programda yer alarak öğretilmesi hedeflenmelidir.

Pek çok öğrenci iyi yazıyı nelerin oluşturduğuna ilişkin sınırlı bilgiye sahiptir. Bu öğrenciler etkili olmayan bir yazma yaklaşımı kullanırlar ve yazma süreçlerinde gelişmiş bir planlama yapamazlar. İçerik üretiminde zorluk yaşayan öğrenciler bir plan yapma ya da gözden geçirme sratejilerini daha az kullanır (Harris, Santangelo ve Graham, 2008). Bu nedenle öğrencilere bildiklerini, gözlem ve yaşantılarını yazma sırasında nasıl kullanabileceklerinin, okuduklarından nasıl yararlanabileceklerinin, bir yazıda söyleneceklerin nasıl bir düzen içerisinde planlayacaklarının iyi öğretilmesi ve kavratılması gerekir (Özdemir, 2008). Bu nedenle yalnızca yazma startejilerinin yerini belirlemek değil aynı zamanda özellikle daha nitelikli yazıların ortaya çıkarılması için yetkin yazarlar tarafindan sıklıkla kullanılan planlama stratejilerinin yerini belirlemek de amaçlanmıştır.

Yazma süreci hem yazma öncesi planlamada hem de yazma sırası ve sonrasında bu nedenle amaca dönük ve stratejik olmalıdır. Böylece yazma öncesi, yazma sırası ve yazma sonrasında yazma stratejilerinin kullanımı ile daha nitelikli yazıların oluşturulması sağlanabilir. Grabe ve Kaplan'a göre (1996), belirli bir bir amaç doğrultusunda yazmak; yazma öncesi hazırlık yapma, yazıyı planlama, gözden gerçirme gibi yazma sürecinde yer alan aşamaların öğrenilmesi ve yazının geliştirilmesi için önemlidir. Bu nedenle yazma becerilerinin geliştirilmesinde etkili stratejilerin seçilerek amaca uygun olarak uygulanması gerekir.

Temel dil becerileri içinde yazma becerisi, diğer dil becerilerine göre daha ağır gelişmekte ve çok sayıda alıştırma yapmayı gerekli kılar (Demirel, 2003). Yazma sürecinde karşılaşan psikolojik, bilişsel ve dilbilgisel sorunlar (Byrne, 1988) öğrencilerin yazma sürecini zor bir beceri olarak algılamalarına neden olur. Bu durum yazmaya yönelik olumsuz bir algı yaratmakta ve doğrudan yazma becerisinin gelişimi üzerinde engel oluşturarak öğrencilerin yazmadan uzak durmalarına neden olur. Yazmaya yönelik bu "zor" algısının değişmesi ve yazma sürecinde yaşanılan sorunların ortadan kaldırılması ve yazma becerisinin geliştirilmesi için ilk olarak karşılaşılan zorluklara stratejik yaklaşılması önerilebilir. Çünkü kimi öğrenciler iyi bir giriş cümlesi yazma konusunda zorluk yaşadıkları için bu öğrencilerin bu alanda çalışmaları gerekirken, kimilerinin herhangi bir metin türünün temel unsurları konusunda çalışması gerekebilir (Mason, Harris ve Graham, 2011). Planlama ve yazma stratejileri; yazma süresince bilişsel olarak yazma amacının belirlenmesi, yazmanın başlatılması, üstbilişsel olarak yazma sürecinin izlenmesi, düzenleme ve denetleme stratejilerinden uygun olan stratejinin seçilmesi ve yazının değerlendirilmesine kadar bir dizi işlemi yerine getirmeyi sağlar (Graham ve Harris, 2005). Yazma stratejileri yazılı dili üretme ile yazma sırasında karşılaşılan sorunları çözme süreçleri olan yazma stratejileri hem bilişsel hem de üstbilişsel düzeyde olabilir (Topuzkanamış, 2014). Yazma sürecini kontrol etme yollarından bir olan bu stratejiler, yazma sürecine uygun olarak düşünce üretmeyi ve üretilen düşünceyi etkili bir yazılı anlatıma dönüştürerek okuyucuya iletmeyi kolaylaştıran araçlardır (Harris, Santangelo ve Graham, 2010). Bu noktada yazma sürecine yardımcı olacak planlama ve yazma stratejilerinin işe koşulması önem taşır. Alanyazında, Türkçe dersi öğretim programlarına ilişkin yapılan çalışmalara bakıldığında (Susar Kırmızı ve Yurdakul, 2019; Eroğlu Çopur, 2019; Yılmaz ve Turan, 2019; Kurudayığlu ve Soysal, 2019; Kıbrıs, 2019; Söylemez, 2018; Bıçak ve Alver, 2018; Bağcı Ayrancı ve Mutlu, 2017; Altunkeser ve Coşkun, 2017; Arı, 2016; Şahin ve Bayramoğlu, 2016; Çakmak ve Altun, 2013; Güzel ve Karadağ, 2013; Baş, 2012; Gündoğdu, 2012; Karadağ, 2012) 2019 Türkçe dersi öğretim programında yer alan yazma öğrenme alanındaki kazanımların değerlendirilmesine ve planlama ve yazma stratejilerinin yerinin belirlenmesine ilişkin herhangi bir araştırmanın yer almadığ belirlenmiştir. Bu nedenle bu araştırmada, 2019 TDÖP’te yazma öğrenme alanındaki kazanımlar ele alınarak bu kazanımlar içinde planlama ve yazma stratejilerinin yerinin belirlenmesi ve programın değerlendirilmesi amaçlanmıştır. 2019 TDÖP ve yazma öğrenme alanı ile sınırlandırılan araştırmanın, programda yer alan yazma öğrenme alanı kazanımlarının durumuna ilişkin alanyazına katk1 sağlayacağı düşünülmektedir. 


\section{Yöntem}

$\mathrm{Bu}$ bölümde araştırmanın modeli, veri toplama araçları, veri toplama süreci ve verilerin analizine değinilmiştir.

\section{Araştırmanın Modeli}

2019 Türkçe dersi öğretim programında planlama ve yazma stratejilerinin yerini belirlemek amacıyla yapılan bu araştırma, bir nitel durum araştırmasıdır. Veriler, doküman incelemesi yoluyla elde edilmiştir. Doküman incelemesi, araştırılması hedeflenen olgu veya olgulara ilişkin bilgi içeren yazılı materyallerin analizini kapsar (Yıldırım ve Şimşek, 2015). Çalışmada temel doküman olarak Türkçe dersi öğretim programında (MEB, 2019) öğrenme alanı olarak yer alan yazma becerisinin kazanımları incelenmiş ve bu kazanımlara ilişkin bulgular değerlendirilerek raporlaştırılmıştır. Araştırmada incelenen kazanımlar sınıf düzeyi olarak beş, altı, yedi ve sekizinci sınıflarda yer alan yazma öğrenme alanı kazanımları ile sınırlandırılmıştır.

\section{Verilerin Analizi}

Araştırmada, doküman analizi yöntemi ile elde edilen veriler içerik analizi tekniğiyle çözümlenmiştir. İçerik analizinde temel amaç, metinden elde edilen verileri açıklayabilecek kavram ve ilişkilere ulaşmaktır (Yıldırım ve Şimşek, 2015). İlk olarak, 2019 TDÖP'te yer alan beş, altı, yedi ve sekizinci sınıf düzeyinde yer alan kazanımlar incelenerek belirlenmiş ve listelenmiştir. Ardından bu kazanımların içeriğinde yer alan planlama ve yazma stratejilerinin bulunma durumlarına ilişkin frekansları çıkarılmış ve kazanımın programda kaç defa ele alındığı belirlenmiştir. Daha sonra veriler listelenerek bulgular bölümünde sunulmuştur.

\section{Bulgular}

$\mathrm{Bu}$ araştırma kapsamında yazma öğrenme alanı bağlamında incelenen 2019 TDÖP'te beşinci, altıncı, yedinci ve sekizinci sınıf düzeyinde yer alan kazanımlar; metin türü bilgisine yönelik kazanımlar, yazma sürecine yönelik kazanımlar, dil bilgisine yönelik kazanımlar ve metnin içeriğini desteklemeye yönelik kazanımlar olarak dört kategoriye ayrılarak incelenmiştir.

\section{Metin Türü Bilgisine Yönelik Kazanımlar}

İlk olarak beşinci, altıncı, yedinci ve sekizinci sınıf düzeyinde yer alan metin türü bilgisine yönelik kazanımlar incelenmiş ve bu kazanımlar Tablo 1'de verilmiştir: 
Tablo 1: Metin Türü Bilgisine Yönelik Kazanımlar

\begin{tabular}{|c|c|c|c|c|}
\hline Metin Türü Bilgisine Yönelik Kazanımlar & Sin & & & \\
\hline & 5 & 6 & 7 & 8 \\
\hline 1.Şiir yazar. & + & + & + & + \\
\hline 2. Bilgilendirici metin yazar. & + & + & + & + \\
\hline $\begin{array}{l}\text { 2.1.Öğrencilerin konu ve ana fikri belirlemeleri, buna göre giriş, gelişme, sonuç bölümlerinde } \\
\text { yazacaklarının taslağını oluşturmaları ve ilk paragrafta amaçlarını ifade etmeleri sağlanır. }\end{array}$ & + & + & & \\
\hline $\begin{array}{l}\text { 2.2.Öğrenciler yeni öğrendikleri kelimeleri kullanmaya ve günlük hayattan örnekler vermeye teşvik } \\
\text { edilir. }\end{array}$ & + & & & \\
\hline 2.3.Anlatımı desteklemek için grafik ve tablo kullanmaları sağlanır. & + & & & \\
\hline 2.4.Öğrenciler yazılarında günlük hayattan örnekler vermeleri için teşvik edilir. & & + & + & + \\
\hline $\begin{array}{l}\text { 2.5.Öğrencilerin giriş, gelişme ve sonuç bölümlerinde yazacaklarını belirleyerek bir metin taslağı } \\
\text { oluşturmaları, düşünceyi geliştirme yollarını kullanmaları, yazılı ve çoklu medya kaynaklarından } \\
\text { görüşlerini destekleyecek kanıtlar sunmaları sağlanır. }\end{array}$ & & & + & \\
\hline $\begin{array}{l}\text { 2.6. Öğrencilerin belirledikleri bir konu ve ana fikir etrafinda giriş, gelişme ve sonuç bölümlerinden } \\
\text { oluşan bir metin taslağı oluşturmaları, gelişme bölümünde düşünceyi geliştirme yollarını kullanarak } \\
\text { görüşlerini ifade etmeleri, görüşlerini destekleyecek kanıtlar sunmaları, sonuç bölümünde ise } \\
\text { görüşlerini sonuca bağlamaları sağlanır. }\end{array}$ & & & & + \\
\hline 3. Hikâye edici metin yazar. & + & + & + & + \\
\hline $\begin{array}{l}\text { 3.1.Öğrencilerin günlük hayattaki gözlem ve deneyimlerine dayanarak hikâye konusu ve hikâye } \\
\text { unsurlarını belirlemeleri sağlanır. }\end{array}$ & + & & & \\
\hline $\begin{array}{l}\text { 3.2.Öğrenciler, yazım kılavuzundan yararlanmaları ve yeni öğrendikleri kelimeleri kullanmaları } \\
\text { için teşvik edilir. }\end{array}$ & + & + & + & \\
\hline $\begin{array}{l}\text { 3.3.Öğrencilerin zaman, mekân, şahıs ve olay unsurlarını belirlemeleri, hikâyenin serim, düğüm ve } \\
\text { çözüm bölümlerinde anlatacaklarının taslağını oluşturmaları sağlanır. }\end{array}$ & & + & + & \\
\hline $\begin{array}{l}\text { 3.4.Öğrencilerin anlatımın türü ve konusuna göre gerçekçi veya hayalî ögeleri tasarlamaları, uyumlu } \\
\text { bir zaman ve mekân kurgusu yapmaları, serim, düğüm ve çözüm bölümlerine yer vermeleri sağlanır. }\end{array}$ & & & & + \\
\hline 3.5.Öğrenciler yazım kılavuzundan yaralanmaya, günlük hayattan örnekler vermeye yönlendirilir. & & & & + \\
\hline 4. Kısa metinler yazar. & + & + & + & + \\
\hline 4.1.Öğrenciler dilekçe yazmaya teşvik edilir. & + & & & \\
\hline 4.2.Duyuru, ilan ve reklam metinleri yazdırılır. & & + & & \\
\hline 4.3.Haber metni ve/veya anı yazmaya teşvik edilir. & & & + & \\
\hline 4.4.Haber metni, günlük ve anı yazmaya teşvik edilir. & & & & + \\
\hline 5.Araştırmalarının sonuçlarını yazılı olarak sunar. & & & + & + \\
\hline $\begin{array}{l}\text { 5.1.Öğrencilerin taslak hazırlamaları, taslaklarında giriş, gelişme, sonuç bölümlerine yer vermeleri } \\
\text { sağlanır. }\end{array}$ & & & + & + \\
\hline 5.2.Kaynak gösterme hakkında bilgi verilir. & & & + & + \\
\hline 6. Formları yönergelerine uygun doldurur. & + & + & + & + \\
\hline
\end{tabular}

Tablo 1'e göre, programda metin türü bilgisine yönelik altı ana kazanım ve bu kazanımlara bağlı 17 alt kazanım yer alır. Bu kazanımlardan beş ana kazanımın dört sınıf düzeyinde ortak kazanım olduğu belirlenmiştir. Yalnızca bir kazanım, yedinci ve sekizinci sınıf düzeyi ile sınırlandırılmıştır. Tablo 1 incelendiğinde, metin türlerinin dört sınıf düzeyinde de şiir, bilgilendirici ve hikâye edici metinler olarak üçe ayrıldığı görülür. Dört sınıf düzeyinde yer alan "Şiir yazar." ana kazanımına ilişkin herhangi bir alt kazanımın bulunmadığı ya da açıklamaya yer verilmediği görülürken diğer ana kazanımlarda çeşitli alt kazanımlara yer verilmiştir. "Bilgilendirici metin yazar." ana kazanımında farklı sınıf düzeylerinde altı alt kazanım yer alır. Bu ana kazanımın alt kazanımında beşinci sınıf düzeyinde yer alan "Öğrenciler yeni öğrendikleri kelimeleri kullanmaya ve günlük hayattan örnekler vermeye teşvik edilir." kazanımının altı, yedi ve sekizinci sınıflarda "Öğrenciler yazılarında günlük hayattan örnekler vermeleri için teşvik edilir." kazanımı ile hedef davranış açısından benzerlik taşıdığı hâlde ayrı iki kazanım yer alır. 
"Hikâye edici metin yazar." ana kazanımında farklı sınıf düzeylerinde beş alt kazanım yer almaktadır. Bu ana kazanımda yer alan üç kazanım, doğrudan hikâye edici metinlerin biçim, içerik, dil ve anlatım ile bağlantılı iken diğer iki kazanımın metin türü içeriği ile bağlantılı olmadığı görülmüştür. Ayrıca metin türü ile bağlantılı olmayan bu iki kazanımdan; beş, altı ve yedinci sınıf düzeylerinde "Öğrenciler, yazım kılavuzundan yararlanmaları ve yeni öğrendikleri kelimeleri kullanmaları için teşvik edilir." kazanımı ile sekizinci sınıf düzeyinde "Öğrenciler yazım kılavuzundan yaralanmaya, günlük hayattan örnekler vermeye yönlendirilir." kazanımının hedef davranış açısından benzerlik taşıdığı hâlde ayrı iki kazanım yer alır.

"Kısa metinler yazar." kazanımı ile beşinci sınıf düzeyinde, dilekçe; altıncı sınıf düzeyinde duyuru, ilan, reklam metni; yedinci sınıf düzeyinde heber metni ve/veya anı; sekizinci sinıf düzeyinde haber metni, günlük ve anı gibi kısa metinler ile farklı türlerde metin yazımının öğretimi hedeflendiği söylenebilir. Ayrıca "Formları yönergelerine uygun doldurur" kazanımı ile de gündelik yaşamda işlevsellik gösteren metin özelliklerinin tüm sınıf düzeylerinde kavratılmasının amaçlandığı düşünülebilir.

\section{Yazma Sürecine Yönelik Kazanımlar}

Bir süreç gerektiren yazma becerisi genel olarak yazma öncesi, yazma sırası ve yazma sonrası süreçlerden oluşur. Programda bu amaçla yazma sürecini içeren çeşitli kazanımlara yer verilmiştir. Bu kazanımlar Tablo 2'de yer aldığı gibidir:

Tablo 2: Yazma Sürecine Yönelik Kazanımlar

\begin{tabular}{|c|c|c|c|c|}
\hline Yazma Sürecine Yönelik Kazanımlar & SiI & & & \\
\hline & 5 & 6 & 7 & 8 \\
\hline 1.Yazdıklarını düzenler. & + & + & + & + \\
\hline 1.1.Sınıf düzeyine uygun yazım ve noktalama kuralları ile sınırlı tutulur. & + & & & \\
\hline $\begin{array}{l}\text { 1.2. Anlam bütünlüğünü bozan ifadelerin belirlenmesi ve düzeltilmesi sağlanır, kavramsal olarak anlatım } \\
\text { bozukluğu konusuna değinilmez. }\end{array}$ & & + & & \\
\hline 1.3.Metinde yer alan yazım ve noktalama kuralları ile sınırlı tutulur. & & + & + & + \\
\hline 1.4.Anlama dayalı anlatım bozuklukları bakımından yazdıklarını gözden geçirmesi ve düzeltmesi sağlanır. & & & + & + \\
\hline $\begin{array}{l}\text { 1.5.Dil bilgisine dayalı anlatım bozuklukları bakımından yazdıklarını gözden geçirmesi ve düzeltmesi } \\
\text { sağlanır. }\end{array}$ & & & & + \\
\hline 2.Yazdıklarını paylaşır. & + & + & + & + \\
\hline 2.1.Öğrenciler, yazdıklarını sınıf ve okul panosu gibi farklı ortamlarda paylaşmaya teşvik edilir. & + & & & \\
\hline 2.2.Öğrenciler yazdıklarını sınıf ve okul panosu ile sosyal medyada paylaşmaya teşvik edilir. & & + & & \\
\hline $\begin{array}{l}\text { 2.3.Öğrenciler yazdıklarını sınıf ve okul panosu ile sosyal medya ortamlarında paylaşmaya, şiir ve } \\
\text { kompozisyon yarışmalarına katılmaya teşvik edilir. }\end{array}$ & & & + & + \\
\hline 3.Yazdıklarının içeriğine uygun başlık belirler. & + & & + & + \\
\hline 4.Yazılarında uygun geçiş ve bağlantı ifadelerini kullanır. & + & + & + & + \\
\hline 4.1.Ama, fakat, ancak ve lakin ifadelerini kullanmaları sağlanır. & + & & & \\
\hline 4.2.Ama, fakat, ancak, lakin, bununla birlikte ve buna rağmen ifadelerinin kullanılması sağlanır. & & + & & \\
\hline 4.3.Oysaki, başka bir deyişle, özellikle, ilk olarak ve son olarak ifadelerini kullanmaları sağlanır. & & & + & + \\
\hline 5.Yazma stratejilerini uygular. & + & + & + & + \\
\hline $\begin{array}{l}\text { 5.1.Güdümlü, metin tamamlama, bir metni kendi kelimeleri ile yeniden oluşturma, boşluk doldurma, grup } \\
\text { olarak yazma gibi yöntem ve tekniklerin kullanılması saglanır. }\end{array}$ & + & & & \\
\hline $\begin{array}{l}\text { 5.2.Güdümlü, serbest, kontrollü, tahminde bulunma, metin tamamlama, bir metni kendi kelimeleri ile } \\
\text { yeniden oluşturma, boşluk doldurma, grup olarak yazma gibi yöntem ve tekniklerin kullanılması sağlanır. }\end{array}$ & & + & & \\
\hline $\begin{array}{l}\text { 5.3. Not alma, özet çıkarma, serbest, kontrollü, kelime ve kavram havuzundan seçerek yazma, bir metinden } \\
\text { hareketle yazma ve duyulardan hareketle yazma gibi yöntem ve tekniklerin kullanılması sağlanır. }\end{array}$ & & & + & \\
\hline
\end{tabular}


Tablo 2'de görüldüğü gibi programda yazma sürecini içeren yazdıklarını düzenlemeye, paylaşmaya, içeriğine uygun başlık belirlemeye, uygun geçiş ve bağlantı ifadelerini kullanmaya ve yazma stratejilerini uygulamaya yönelik beş ana kazanım bulunur. Bu kazanımlardan "Yazdıklarını düzenler." kazanımı, yazmanın en önemli aşamasını içeren düzenleme aşamasına yönelik bir kazanım olarak görülse de alt kazanımlarında yer alan içeriğe bakıldığında bir dil bilgisi kazanımı içeriğine sahip olduğu belirlenmiştir. İlgili kazanımda bulunan beşinci sınıf düzeyindeki "Sınıf düzeyine uygun yazım ve noktalama kuralları ile sınırlı tutulur." ve "Metinde yer alan yazım ve noktalama kuralları ile sınırlı tutulur." alt kazanımları yazıyı yazım kuralları açısından düzenlemeyi hedeflerken aslında bir dil bilgisi konusu olan yazım ve noktalama işaretleri kazanımına işaret eder. Benzer biçimde altıncı sınıf düzeyindeki "Anlam bütünlüğünü bozan ifadelerin belirlenmesi ve düzeltilmesi sağlanır, kavramsal olarak anlatım bozukluğu konusuna değinilmez." ile yedinci sınıf düzeyindeki "Anlama dayalı anlatım bozuklukları bakımından yazdıklarını gözden geçirmesi ve düzeltmesi sağlanır." ve sekizinci sınıf düzeyinde "Dil bilgisine dayalı anlatım bozuklukları bakımından yazdıklarını gözden geçirmesi ve düzeltmesi sağlanır." alt kazanımları yazıyı anlatım açısından düzenlemeyi hedeflerken aslında bir dil bilgisi konusu olan anlatım bozuklukları konusunun kazanımlarına işaret eder.

"Yazdıklarını paylaşır." kazanımı ile beşinci sınıf düzeyinde, yazdıklarını sınıf ve okul panosu gibi farklı ortamlarda paylaşmaları, altıncı sınıf düzeyinde sınıf ve okul panosu ile sosyal medyada paylaşmaları, yedi ve sekizinci sınıf düzeyinde sınıf ve okul panosu ile sosyal medya ortamlarında paylaşmaları, şiir ve kompozisyon yarışmalarına katılmaları sağlanarak öğrencilerin kendilerini yazılı olarak ifade etme alışkanlığı kazandırılması hedeflendiği düşünülebilir. Yazma sürecinin önemli aşamalarından biri yazılı ürüne bașlık belirlemedir. "Yazdıklarının içeriğine uygun başlık belirler." kazanımı diğer üç sınıf düzeyinde bulunduğu hâlde altıncı sınıfta bulunmadığı görülür. "Yazılarında uygun geçiş ve bağlantı ifadelerini kullanır." tüm sınıf düzeylerinde yer almakta beşinci sınıfta "ama, fakat, ancak ve lakin", altıncı sınıfta "ama, fakat, ancak, lakin, bununla birlikte ve buna rağmen" yedinci ve sekizinci sınıfta "oysaki, başka bir deyişle, özellikle, ilk olarak ve son olarak" ifadelerini kullanmaları hedeflenmiştir.

Tablo 2'de yazma stratejilerine yönelik bir ana kazanımın ve bu kazanımlara bağlı üç alt kazanımın yer aldığı görülmüştür. İlgili kazanımların her sınıf düzeyinde aşamalı olarak yapılandırıldığı ve her sınıf düzeyinde "Yazma stratejilerini uygular." kazanımın yer aldığı ve bu kazanımın altında beşinci sınıf düzeyinde "Güdümlü, metin tamamlama, bir metni kendi kelimeleri ile yeniden oluşturma, boşluk doldurma, grup olarak yazma gibi yöntem ve tekniklerin kullanılması sağlanır.", altıncı sınıf düzeyinde "Güdümlü, serbest, kontrollü, tahminde bulunma, metin tamamlama, bir metni kendi kelimeleri ile yeniden oluşturma, boşluk doldurma, grup olarak yazma gibi yöntem ve tekniklerin kullanılması sağlanır." ile yedi ve sekizinci sınıf düzeyinde "Not alma, özet çıkarma, serbest, kontrollü, kelime ve kavram havuzundan seçerek yazma, bir metinden hareketle yazma ve duyulardan hareketle yazma gibi yöntem ve tekniklerin kullanılması sağlanır." alt kazanımları yer alır.

\section{Dil bilgisine Yönelik Kazanımlar}

Programda dil bilgisi konularının ayrı bir başlık olarak ele alınmadığı diğer öğrenme alanlarının içinde yer alır. Burada yazma öğrenme alanı içinde beşinci, altıncı, yedinci ve sekizinci sınıf düzeyinde dil bilgisine yönelik kazanımlar incelenmiş ve bu kazanımlar Tablo 3 'te verilmiştir: 
Tablo 3: Dil bilgisine Yönelik Kazanımlar

\begin{tabular}{|c|c|c|c|c|}
\hline \multirow[t]{2}{*}{ Dil bilgisine Yönelik Kazanımlar } & \multicolumn{4}{|c|}{ Sinif } \\
\hline & 5 & 6 & 7 & 8 \\
\hline $\begin{array}{l}\text { 1. Yazılarında ses olaylarına uğrayan kelimeleri doğru kullanır. } \\
\text { Ünlü düsmesi, ünlü daralması, ünsüz benzeşmesi, ünsüz yumuşaması ve ünsüz türemesi ses olaylarl } \\
\text { üzerinde durulur. }\end{array}$ & + & & & \\
\hline 2.Ek fiili işlevlerine uygun olarak kullanır. & & & + & \\
\hline 3.Cümlenin ögelerini ayırt eder. & & & & + \\
\hline $\begin{array}{l}\text { 4.Cümle türlerini tanır. } \\
\text { Kavramsal tanimlamalara girilmez. }\end{array}$ & & & & + \\
\hline $\begin{array}{l}\text { 5.Fiillerin çatı özelliklerinin anlama olan katkısını kavrar. } \\
\text { Kavram tanımlarına girilmeden anlamsal farklılıklara değinilir. }\end{array}$ & & & & + \\
\hline $\begin{array}{l}\text { 6.Büyük harfleri ve noktalama işaretlerini uygun yerlerde kullanır. } \\
\text { Yay ayraç, ü̧̧ nokta, eğik çizgi, soru işareti, nokta, virgül, iki nokta, ünlem, tırnak işareti, kisa } \\
\text { çizgi, konuşma çizgisi, kesme işareti, noktall virgül ve köşseli ayraç işaretlerinin yaygın kullanılan } \\
\text { işlevleri üzerinde durulur. }\end{array}$ & + & & & \\
\hline $\begin{array}{l}\text { 7. Sayıları doğru yazar. } \\
\text { Kesirli saylların, sıra ve üleştirme sayılarının, dört veya daha çok basamakl sayıların yazımları } \\
\text { üzerinde durulur. }\end{array}$ & + & & & \\
\hline $\begin{array}{l}\text { 8.Yazdıklarında yabancı dillerden alınmış, dilimize henüz yerleşmemiş kelimelerin Türkçelerini } \\
\text { kullanır. }\end{array}$ & + & + & + & + \\
\hline
\end{tabular}

Tablo 3'e göre yazma öğrenme alanı içinde yer alan sekiz dil bilgisi kazanımı vardır. $\mathrm{Bu}$ kazanımlardan beşi doğrudan dil bilgisi konularını içerirken diğer üçü yazım kuralları ile ilgilidir. $\mathrm{Bu}$ kazanımlardan "Yazdıklarında yabancı dillerden alınmış, dilimize henüz yerleşmemiş kelimelerin Türkçelerini kullanır." kazanımı dört sınıf düzeyinde de yer alan ortak kazanımdır. Diğer dil bilgisi kazanımları ise öğrencilerin hazırbulunuşluklarına göre çeşitli sınıf düzeylerine yayılmıştır. Örneğin, yedinci sınıf düzeyinde bir kazanım, sekizinci sınıf düzeyinde ise üç dil bilgisi kazanımı yer alır. Altıncı sınıf düzeyinde yazma öğrenme alanında herhangi bir dil bilgisi kazanımının bulunmadığı belirlenmiştir. Yazım kurallarına ilişkin "Büyük harfleri ve noktalama işaretlerini uygun yerlerde kullanır." ve "Sayıları doğru yazar." kazanımlarının ise yalnızca beşinci sınıf düzeyinde yer alır. Diğer sınıf düzeylerinde yazım kurallarına ilişkin dil bilgisi kazanımının yer almadığı bulgulanmıştır.

\section{Metnin İçeriğini Desteklemeye Yönelik Kazanımlar}

Programda metin türü bilgisine, yazma sürecine ve dil bilgisine yönelik olan kazanımların incelenmesinin ardından kalan yedi kazanım metnin içeriğini desteklemeye yönelik kazanımlar olarak kategorize edilmiştir. İlgili kazanımlara ilişkin bulgular Tablo 4’te verilmiştir.

Tablo 4: Metnin İçeriğini Desteklemeye Yönelik Kazanımlar

\begin{tabular}{|c|c|c|c|c|}
\hline Metnin İçeriğini Desteklemeye Yönelik Kazanımlar & Sin & & & \\
\hline & 5 & 6 & 7 & 8 \\
\hline 1.Yazdıklarını desteklemek için gerektiğinde grafik ve tablo kullanır. & & + & & \\
\hline 2.Anlatımı desteklemek için grafik ve tablo kullanır. & & & + & + \\
\hline 3.Bir işin işlem basamaklarını yazar. & + & & & \\
\hline 4.Bir işi işlem basamaklarına göre yazar. & & + & + & + \\
\hline 5.Yazılarını zenginleştirmek için atasözleri, deyimler ve özdeyişler kullanır. & + & + & + & + \\
\hline 6.Yazılarında anlatım biçimlerini kullanır. & & & + & + \\
\hline 7.Yazılarında mizahi ögeler kullanır. & & & & + \\
\hline
\end{tabular}


Tablo 4'e göre metnin içeriğini desteklemeye yönelik olarak yedinci ve sekizinci sınıf düzeyinde anlatım biçimlerinden, sekizinci sınıf düzeyinde ise mizahtan yararlanmayı hedefleyen kazanımlar yer alır. Ayrıca her sınıf düzeyinde anlatımı güçlendirmek için öğrencilerin atasözleri, deyim ve özdeyiş kullanmasına teşvik eden bir kazanım da yer alır. Bu kazanımlardan yedi ve sekizinci sınıf düzeyinde "Yazdıklarını desteklemek için gerektiğinde grafik ve tablo kullanır." kazanımı ile beşinci sınıf bilgilendirici metin yazma kazanımında alt kazanım olarak "Anlatımı desteklemek için grafik ve tablo kullanmaları sağlanır." kazanımı hedef davranış açısından benzerlik taşıdığı hâlde ayrı iki ayrı kazanım olarak ifade edildiği görülmüştür. Beşinci sınıf düzeyinde yer alan "Bir işin işlem basamaklarını yazar." ve altı, yedi ve sekizinci sınıf düzeyinde "Bir işi işlem basamaklarına göre yazar." kazanımları hedef davranış açısından benzerlik taşıdığı hâlde ayrı iki kazanım olarak ifade edildiği görülmüştür.

\section{Tartışma, Sonuç ve Öneriler}

$\mathrm{Bu}$ araştırmada 2019 TDÖP yazma öğrenme alanı boyutu ile planlama ve yazma stratejileri bağlamında ele alınmıştır. Araştırmanın sonucunda, 2019 TDÖP'te bulunan yazma becerisine yönelik kazanımlar incelenmiş ve elde edilen sonuçlar tartışılarak programı geliştirmeye yönelik çeşitli öneriler sunulmuştur. Araştırmada ilk olarak yazma öğrenme alanındaki kazanımların hem genel olarak hem de her sınıf düzeyinde ayrı olarak yeterince ayrıntılandırılmadığı sonucuna ulaşılmıştır. Programda yazma öğrenme alanına ilişkin kazanımlar sınıf seviyesine göre belirtilmiş ancak bu programda dil bilgisi ile ilgili kazanımlar çeşitli öğrenme alanları içinde planlandığından eski programlar ile karşılaştıııldığında (2006 ve 2015 TDÖP) bu programda yazma kazanımlarının yeterliği ve kapsamının sınırlandırıldığı görülmüsştür. Genel olarak programda gerçekleştirilen yazma öğrenme alanına yönelik düzenlemelerin yine önceki programa (2015 TDÖP) oranla daha az olduğu, öğrenme alanlarına ilişkin kazanımların daha az ana kazanım ve alt kazanım olarak gruplandırıldığı ve kazanımlara ilişkin yeterince açıklama yapılmadığından söz edilebilir. Benzer biçimde, Kurudayığlu ve Soysal (2019), Türkçe dersi öğretim programını (2018) 21.yüzyıl becerileri açısından inceledikleri çalışmalarında, 2018 programında kazanımların yeterli ve dengeli bir biçimde yer almadığını belirtir. Ancak kazanımların öğretim programında hangi öğrenme ya da beceri alanı olursa olsun yeterli, dengeli ve sistemli bir biçimde yer verilmelidir.

İkinci olarak programda yer alan bazı kazanımların birbirine benzer hedef davranışta olduğu hâlde farklı kazanım cümleleri ile ifade edildiği belirlenmiştir. Benzer biçimde Baş'ın (2012), 2006 TDÖP kazanımlarından hareketle yaptığı araştırmada ve Durukan'ın (2013), 2005 TDÖP kazanımlarına ilişkin öğretmen görüşlerini incelediği çalışmada ilgili programlarda öğrenme alanlarının aynı ölçüde değerlendirilmediği ve kazanımların birbiri ile benzerlik taşıdığı sonucuna ulaşmışlardır. Susar Kırmızı ve Yurdakul (2019) çalışmalarında, 2018 ilkokul TDÖP' e ilişkin sınıf öğretmenlerinin de programda yer alan yöntem-teknik konularında açıklamaların yetersiz olduğu ve kazanımların düzensiz bir sıra izlediğine yönelik görüş bildirdiklerini belirtir. Bu araştırmada da benzer bir sonuca ulaşılması nedeniyle araştırmadan elde edilen bu sonuç ile birbirine benzer hedef davranışı içeren kazanımların gözden geçirilerek yeniden düzenlenmesi ve sınıflandırılması önerilebilir.

Üçüncü olarak programda yazım kurallarına ilişkin çok az kazanımın yer aldığg ve ilgili kazanımlara ilişkin de herhangi bir açıklamanın yer almadığı görülmüştür. Yazım kurallarına ilişkin bazı kazanımların yalnızca beşinci sınıf düzeyinde yer aldığı ve diğer sınıf düzeylerinde "Yazdıkları düzenler." kazanımı ile ilişkili olarak yer verilmiştir. Diğer sınıf düzeylerinde yazdıklarını düzenleme kazanımı dışında yazım kurallarına ilişkin dil bilgisi kazanımının yer almadığ 1 bulgulanmıştır. Oysa yazım kuralları öğrencilerin uygulama noktasında en çok sıkıntı yaşadıkları alanlardan biri olduğundan farklı sınıf düzeylerinde çeşitli kazanımlarla sarmal olarak öğretilmesi gereken bir konudur. Alanyazında yer alan pek çok çalışma bu bulguyu kanıtlar niteliktedir. Demir (2013) 
araştırma sonuçlarında incelenen kompozisyonlarda öğrencilerin en önemli eksikliklerinin noktalama işaretlerini kullanamama, yazım kurallarına uymama, amaca uygun kelime seçememe, mantıkça doğru ve dil kurallarına uygun cümleler kuramama olduğunu belirlemiştir. Bıçak ve Alver (2018), 2018 TDÖP'e ilişkin öğretmen görüşlerini incelediği çalışmasında, araştırmaya katılan öğretmenlerin de görüşlerinin dil bilgisi ve yazım konularının sınıflara göre dağılımının yeniden gözden geçirilmesi gerektiği yönündedir. Araştırma sonunda ulaşılan ve alanyazındaki bulgularla desteklenen bu sonuçla birlikte, programdaki yazım kurallarına yönelik kazanımlarının düzenlenmesi ve her sınıf seviyesine uygun kazanımlara ayrıntılı olarak yer verilerek programın yazım kurallarına yönelik olarak gözden geçirilerek yeniden yapılandırılması önerilebilir.

Dördüncü olarak program metin türü bağlamında değerlendirildiğinde, programda genel olarak hikâye edici, bilgilendirici metinler ve şiir olmak üzere üç türden yararlanıldığı ve metin türlerinin bu üç türle sınırlı olduğu ve en çok hikâye edici metin türüne yönelik açıklamaların yer aldığı belirlenmiştir. Benzer biçimde Şahin ve Bayramoğlu (2016) çalışmasında, programda yer alan metin türlerinin hikâye edici metin türü lehine olduğunu belirtmiştir. Altunkeser ve Coşkun (2017) da, 2009 ve 2015 programlarını karşılaştırıp değerlendirdiği çalışmasında her iki programda da benzer biçimde hikâye edici metin türünün baskın olduğunu bulgulamıştır. Metin türü bilgisine yönelik kazanımların sarmal yapısının olduğu ve kazanımların çoğunun sınıf düzeyinde benzer olarak yapılandırıldığı söylenebilir. Kıbrıs (2019) çalışmasında, 2018 TDÖP'te beşinci sınıfta hikâye unsurlarının belirlenerek tür bilgisinin sağlanması ve ardından altıncı ve yedinci sınıfta metin taslaklarının oluşturulmasına yönelik kazanımların yer alarak Türkçe dersi öğretim programı ve ders kitaplarında 'metin türü farkındalı̆̆ı' oluşturulmaya çalışıldığını belirtmiştir.

Alanyazında benzer biçimde Eroğlu Çopur (2019) yaptığı çalışmada; TDÖP (2018) beş, altı, yedi ve sekizinci sınıfta hikâye edici metinlere yönelik kazanımları incelemiş bu kazanımların tüm sınıflar için açıklamalar yaparak, sınıf düzeylerine göre kolaydan zora, basitten karmaşığa sıralanmasını programın olumlu bir yönü olarak değerlendirmiştir. Ayrıca Yılmaz ve Turan (2019), Türkçe öğretim programında yer alan öğrenme alanları ile dijital hikâye anlatımı ilişkisini incelediği çalışmasında dinleme ve izleme, yazma, okuma ve konuşma ile ilgili birçok kazanımın dijital hikâye anlatımı ile örtüştüğü ama en çok yazma beceri alanına ait kazanımlar ile örtüştüğünü belirleyerek araştırmanın bulgusu ile benzerlik taşıyan bir sonuca ulaşmıştır. Anadili eğitiminin bir beceri eğitimi olduğu kadar birtakım öğretimsel bilgileri de içeren bir eğitim süreci olduğu düşünüldüğünde metinlere yönelik istendik becerilerin kazandırılabilmesi için öğrencilerin metin türü bilgisine ilişkin donanımlı bir bilgiye sahip olmaları gerekir. Sever (2005) anadili öğretiminin ilköğretimin ilk yılından başlayarak daha çok seviyeye uygun edebî metinlerle (masal, şiir, öykü vb.) gerçekleştirildiğini vurgular. Buradan hareketle, programın öğretme yaklaşım ve amaçları doğrultusunda metin türü seçiminin genişletilmesi, farklı ve yeni metin türlerine de yer verilmesi önerilebilir.

Beşinci olarak, program planlama ve yazma stratejileri bağlamında incelendiğinde planlama ve yazma stratejilerine ilişkin her sınıf düzeyinde yalnızca "strateji” sözcüğünün bir kavram olarak yer aldığı görülmüş ve her sınıf düzeyinde yalnızca tek bir "Yazma stratejilerini uygular." kazanımının olduğu belirlenmiştir. Ayrıca programda, yazma eğitiminde planlamadan söz edilmemiş ve planlama stratejilerine ilişkin herhangi bir kazanıma yer verilmemiştir. Oysa Altunkeser ve Coşkun (2017), 2009 ve 2015 programlarını karşılaştırıp değerlendirdiği çalışmasında 2015 programı özelinde yazma öğrenme alanında yazma kurallarını uygulama, planlı yazma, farklı türlerde metinler yazma, kendi yazdıklarını değerlendirme, kendini yazılı olarak ifade etme alışkanlığı kazanma, yazım ve noktalama kurallarını kavrama ve uygulama ile ilgili amaçlara yönelik kazanımlar bulunduğunu belirtir. Programda her sınıf düzeyinde yer alan "Bilgilendirici metin yazar." kazanımına bağlı olarak sınıf düzeyine göre değişen "Öğrencilerin konu ve ana fikri belirlemeleri, buna göre giriş, gelişme, sonuç bölümlerinde yazacaklarının taslağını oluşturmaları ve 
ilk paragrafta amaçlarını ifade etmeleri sağlanır.", "Öğrencilerin giriş, gelişme ve sonuç bölümlerinde yazacaklarını belirleyerek bir metin taslağı oluşturmaları, düşünceyi geliştirme yollarını kullanmaları, yazılı ve çoklu medya kaynaklarından görüşlerini destekleyecek kanıtlar sunmaları sağlanır." ve "Öğrencilerin belirledikleri bir konu ve ana fikir etrafında giriş, gelişme ve sonuç bölümlerinden oluşan bir metin taslağı oluşturmaları, gelişme bölümünde düşünceyi geliştirme yollarını kullanarak görüşlerini ifade etmeleri, görüşlerini destekleyecek kanıtlar sunmaları, sonuç bölümünde ise görüşlerini sonuca bağlamaları sağlanır." alt kazanımlarında "taslak" metin oluşturma ifadesinin geçmesi nedeniyle yazma sürecinin planlama aşamasından ve taslak metin oluşturma sürecinden söz edildiği ve bu kazanımların planlama stratejilerine yönelik olarak ele alındığı öne sürülebilir. Yine her sınıf düzeyinde "Hikâye edici metin yazar." kazanımına bağlı olarak sınıf düzeyine göre değişen "Öğrencilerin zaman, mekân, şahıs ve olay unsurlarını belirlemeleri, hikâyenin serim, dügüm ve çözüm bölümlerinde anlatacaklarının taslağını oluşturmaları sağlanır." ve "Öğrencilerin anlatımın türü ve konusuna göre gerçekçi veya hayalî ögeleri tasarlamaları, uyumlu bir zaman ve mekân kurgusu yapmaları, serim, düğüm ve çözüm bölümlerine yer vermeleri sağlanır." kazanımlarında da benzer durumda olduğu görülür.

Programda yazma sürecini içeren yazdıklarını düzenlemeye, paylaşmaya, içeriğine uygun başlık belirlemeye, uygun geçiş ve bağlantı ifadelerini kullanmaya ve yazma stratejilerini uygulamaya yönelik kazanımların yazmanın en önemli aşamasını içeren yazmayı düzenleme aşamasına yönelik kazanımlar olarak görülse de alt kazanımlarında yer alan içeriğe bakıldığında bir dil bilgisi kazanımı içeriğine sahip olduğu belirlenmiştir. İlgili alt kazanımları yazıyı çeşitli yönlerden düzenlemeyi hedeflerken aslında bir dil bilgisi konusu kazanımlarına işaret eder. Yazma sürecinde düzenleme aşaması önemli bir aşamadır ve bu nedenle bu kazanım altında dil bilgisine yönelik değil yazma sürecini düzenlemeye yönelik kazanımların yer alması gerekir. Programda yer alan bu kazanımların bu bulgular ışığında düzenlenmesi önerilebilir.

Programda "Yazdıklarının içeriğine uygun başlık belirler." ve "Yazılarında uygun geçiş ve bağlantı ifadelerini kullanır." kazanımları ilk bakışta planlama ve yazma stratejilerine işaret eden kazanımlar olarak yorumlanabilir. Fakat yazma becerisine yönelik programda yer alan bu kazanımların doğrudan strateji kullanımına odaklanan bir model olmadığı, "strateji” sözcüğünün amacına uygun bir kullanımı önermediği ve bu sözcüğün yalnızca bir terim olarak kazanımlarda yer aldığ 1 görülür. Bu kazanım tüm sınıf düzeylerinde yer almaktadır ancak yalnızca zıtlık ve sıralama bildiren bağlantı öğelerinin kullanımı ile sınırlandırıldığı belirlenmiştir. Oysa bir yazılı ürünün tümceler yığını değil de bir metin oluşturabilmesi, metnin bağdaşık ve tutarlı olabilmesi için metinde geçen dilsel öğelerin yazılan her metin türü ile uyum içinde olması gerekir. Bu uyumu sağlayacak olan araçlar ise metinde kullanılan bağlantı ögeleridir. Bu nedenle programda bağlantı öğelerini kullanmaya yönelik olan kazanımlar çeşitlendirilmeli, yalnızca zıtlık ve sıralama bildiren bağlantı öğelerine değil tüm diğer işlevlerde olan bağlantı öğlerine de kazanımlarda yer verilmelidir. Bağlantı öğeleri, metin türüne uygun olarak ayrıtıntılandırılmalı, her sınıf düzeyinde yer alan etkinlik ve uygulamalarla öğretilmesi amaçlanmalıdır.

Ayrıca programda her sınıf düzeyinde yer alan "Yazma stratejilerini uygular." kazanımları altında strateji kullanımı değil çeşitli yazma yöntem ve tekniklerinin kullanımı örneklendirilmiştir. Stratejiler sorun odaklı bir kullanımı gerektirdiğinden (Oxford, 1990) bir beceriye yönelik strateji kullanımı, o beceriye yönelik yöntem ve tenik kullanımından farklıdır. Bu farkın anlaşılması için strateji kullanımının bir etkinlik olmadığının ve her bir stratejinin kendi kullanım mantığı içerisinde tüm yazma sürecinde, sürekli kullanabilecek işlemler dizisi olduğunun vurgulanması gerekir. 2019 TDÖP'te öğrencilere yazmaya yönelik stratejilerin ne olduğu öğretilmemekte strateji adı altında, sadece etkinlikler içerisinde bazı yöntem ve tekniklerin kullanılması önerilir. Buradan hareketle, programda strateji kullanımının etkinlik temelli algılandığı, strateji kullanmanın sürekliliğine değinilmediği ve programın yazma stratejilerini öğretecek, yazma sürecinde strateji kullanımını destekleyecek bir yapıda olmadığı söylenebilir. Yazma becerisinin istendik düzeyde olması için 
yazma sürecinin stratejik bir biçimde düzenlenip bireylerde özdüzenleme becerilerini de geliştirecek çeşitli yazma stratejilerinin öğretiminin gerçekleştirilmesi, planlama ve yazma stratejilerine ilişkin kazanımların olması ve tüm bunların öğretim programı ile bütünleştirilerek etkinliklerde yer alması gerekir.

Son olarak programda bir süreç olarak yazmanın yer alış biçimine bakıldığında 2019 TDÖP'te yazma becerisi alanındaki kazanımlarda her sınıf düzeyinde yer alan kazanımlar içinde yazma öncesi "planlama" aşamasına ilişkin bir kazanım olmadığı görülür. Programda planlama ile yalnızca "Öğrencilerin taslak hazırlamaları, taslaklarında giriş, gelişme, sonuç bölümlerine yer vermeleri sağlanır." ve "Öğrencilerin konu ve ana fikri belirlemeleri, buna göre giriş, gelişme, sonuç bölümlerinden oluşan bir metin taslağı oluşturmaları, bu bölümlerde yazacaklarını belirlemeleri sağlanır." biçiminde yalnızca iki kazanım ilişkilendirilebilir. Yazma becerisinin geliştirilmesine yönelik kazanımların yer aldığı bu 2019 TDÖP'te yazmanın planlama sürecine yeterince önem verilmediği görülür. Yazma becerisinin stratejik bir süreç içerisinde ele alınıp geliştirilmesi için programda stratejilere ilişkin kazanımların yer alması gerekir. Bu nedenle bu araştırmadan elde edilen sonuçlar, TDÖP'ün öğretim hedefleri içerisine yazma öncesi planlama stratejileri öğretiminin ve yazma sırasında ve sonrasında yazma stratejilerinin eklenmesine bir öneri niteliği taşır.

Programda yazılı ürünü paylaşma aşamasına yönelik her sınıf düzeyinde sınıf panosundan sosyal medyaya kadar farklı ortamlarda paylaşımın yapılabilmesi amaçlanmıştır. Bu kazanımlar ile programda öğrencileri çağın gereklerine uygun olarak yetiştirme amacıyla yazma sürecini yalnızca öğretimsel bir etkinlik değil yaşamsal bir etkinlik olduğuna ilişkin öğrencilerin farkındalık kazanmalarına yönelik yerinde kazanımlar olduğu söylenebilir. Ayrıca şiir ve kompozisyon yarışmalarına katılmaları sağlanarak yazmanın kalıcı bir alışkanlık olmasını sağlamak adına önemli bir adımdır. "Yazdıklarında yabancı dillerden alınmış, dilimize henüz yerleşmemiş kelimelerin Türkçelerini kullanır." kazanımı dört sınıf düzeyinde de yer alan ortak kazanımdır. Bu kazanım, öğrencilere dil duyarlılığını aşılamak ve anadili duyarlılığına sahip bireyler yetiştirmek için oldukça önemli bir kazanımdır. Programda yer alan "Formları yönergelerine uygun doldurur" kazanımı gündelik yaşamda işlevsellik gösteren metin özelliklerinin tüm sınıf düzeylerinde kavratılmasına ve yine öğretim programı ile günedelik yaşam becerileri arasındaki bağı güçlendirmeye yönelik etkili bir kazanımdır.

Sonuç olarak Türkçe öğretmenlerinin yazma stratejilerini bilerek uygulamaları ve öğretimini gerçekleştirebilmeleri için farkındalık kazanmaları gerekir. Bu gereklilik dil öğretiminin stratejik olması ve tüm temel dil becerilerinin stratejik olarak öğretimi ile gerçekleşebilir. Bu öğretim, öğretim programları ile gerçekleştirildiğinden elde edilen sonuçlar ile programa yönelik çeşitli öneriler sunmak önem taşır. Anadili öğretiminde özelde yazma becerisine yönelik öğretim sürecinde ve gerçekleştirilen yazma etkinliklerinde stratejilerden yararlanılması hem öğrenciye hem öğretmene yazma sürecinde katkı sağlayacaktır. Bu nedenle lisans düzeyinde yazma eğitimi dersinde Türkçe öğretmeni adaylarının strateji kullanımı konusunda bilgileri geliştirilmeli ve stratejileri uygulama sürecine yönelik etkinlikler yapılmalıdır. Ayrıca iş başındaki öğretmenlere çeşitli hizmetiçi eğitimler verilerek strateji kullanımına ilişkin bilgileri artırılmalı ve derslerde daha çok uygulama yapmaları sağlanmalıdır.

Alanyazında gerçekleşecek olan gelecekteki araştırmalara yönelik ilk olarak, uygulanmakta olan 2019 TDÖP ile daha önceki programlar ya da sonrasında yapılacak düzenlemeler 1şığında program karşılaştırılmasına yönelik çalışmaların yapılması önerilebilir. Bu araştırma, öğrenme alanı olarak yazma ile ve sınıf düzeyi olarak ortaokul beş, altı, yedi ve sekizinci sınıflar ile sınırlandırılmıştır. Bu nedenle gelecek çalışmalarda tüm öğrenme alanları ve sınıf düzeylerinde daha ayrıntılı olarak çeşitli incelemeler yapılabilir. Ayrıca çalışmalarda standart ölçme araçları kullanılarak elde edilecek nicel verilerle çeşitli çalışmalar oluşturularak daha kapsamlı sonuçlara ulaşılabilir. 


\section{Kaynakça}

Altunkeser, F. ve Coşkun, İ. (2017). 2009 ve 2015 Türkçe dersi öğretim programlarının karşılaştırılması ve değerlendirilmesi. Trakya Üniversitesi Eğitim Fakültesi Dergisi, USOS 2016 Özel Saylsl, 114-135. http://dx.doi.org/10.24315/trkefd.366695

Arı, G. (2016). Türkçe dersi (1-8. sınıflar) öğretim programı sözlü iletişim öğrenme alanındaki kazanımlara eleştirel bir bakış. Sakarya University Journal of Education, 6(2), 235-253. Doi number: http://dx.doi.org/10.19126/suje.40827.

Arı, G. ve Keskin, H. K. (2016). Türkçe dersi (1-8. sınıflar) öğretim programı okuma öğrenme alanındaki kazanımlarla ilgili eleştirel bir değerlendirme. Sakarya Üniversitesi Eğitim Fakültesi Dergisi, 32, 144-169.

Avrupa Yeterlilikler Veri Tabanı (2019). Avrupa yeterlilikler çerçevesi. Erişim Adresi: http://portal.tyc.gov.tr/.

Bağcı Ayranc1, B. ve Mutlu, H. (2017). 2006, 2015 ve 2017 Türkçe dersi öğretim programlarının karş1laştırılması. International Journal of Language Academy, 5(7), 119-130. Doi Number: http://dx.doi.org/10.18033/ijla.3793

Baş, B. (2012). İlköğretim Türkçe programına sözlü ve yazılı kültür temelli bir eleştiri. Kastamonu Eğitim Dergisi, 20(1), 271-290.

Bıçak, N. ve Alver, M. (2018). 2018 Türkçe dersi öğretim programına ilişkin öğretmen görüşleri. Uluslararası Türkçe Edebiyat Kültür Eğitim Dergisi, 7(4), 2480-2501.

Byrne, D. (1988). Teaching writing skills. Longman.

Çakmak, E. ve Altun, A. (2013). İlköğretim Türkçe dersi öğretim programında medya okuryazarlığı eğitimi. Journal of Theory and Practice in Education, 9(2), 152-170.

Demir, T. (2013). Yazma becerisine yönelik kazanımların ortaokulda gerçekleşme düzeyi. Okuma Yazma Eğitimi Araştırmaları, 1(1), 45-56.

Demirel, Ö. (2003). Türkçe ögrretimi. PegemA yayıncılık.

Durukan, E. (2013). Öğretmen görüşleri açısından türkçe dersi öğretim programı kazanımları. Karadeniz Sosyal Bilimler Dergisi, 5(8). Retrieved from: https://dergipark.org.tr/tr/pub/ksbd/issue/16223/169903.

Eroğlu Çopur, D. (2019). 2018 Türkçe dersi öğretim programının 5, 6, 7 ve 8. sınıflar için hikâye edici metinlere yönelik kazanımlar bakımından incelenmesi. International Journal of Educational Spectrum, 1(1), 48-59.

Grabe, W. ve Kaplan, R. B. (1996). Theory and practice of writing. Longman.

Graham, S., Harris, K. R. ve Mason, L. (2005). Improving the writing performance, knowledge, and self-efficacy of struggling young writers: The effects of selfregulated strategy development. $\begin{array}{llll}\text { Contemporary Esychology, } & 30(2),\end{array}$ https://doi.org/10.1016/j.cedpsych.2004.08.001

Guthrie, J. T., Wigfield, A., Barbosa, P., Perencevich, K. C., Taboada, A., Davis, M. H., Scaffidi, N. ve Tonks, S. (2004). Increasing reading comprehension and engagement through conceptoriented reading instruction. Journal of Educational Psychology, 96(3), 403-423. http://dx.doi.org/10.1037/0022-0663.96.3.403

Gündoğdu, A. E. (2012). Türkçe dersi öğretim programının kavram öğretimi açısından incelenmesi. Dicle Üniversitesi Sosyal Bilimler Enstitüsü Dergisi, 4(7), 31-44. 
Güneş, F. (2007) Türkçe öğretimi ve zihinsel yapılandırma. Nobel Yayınevi.

Güzel, A. ve Karadağ, Ö. (2013). Anlatma becerileri açısından “Türkçe Dersi Öğretim Programı”na (6, 7, 8. Sınıflar) eleştirel bir bakış. Ana Dili Eğitimi Dergisi, 1(1), 45-52.

Harris, K. R., Santangelo, T. ve Graham, S. (2008). Self-regulated strategy development in writing: Going beyond NLEs to a more balanced approach. Instructional Science, 36(5-6), 395-408. https://doi.org/10.1007/s11251-008-9062-9.

Harris, K. R., Santangelo, T. ve Graham, S. (2010). Metacognition and strategies instruction in writing. Guilford Press.

İpşiroğlu, Z. (1993). Yazma eylemi. Cem Yay.

Kavcar, C., Oğuzkan, A. F. ve Aksoy, Ö. (2012). Yazılı ve sözlü anlatım. Anı Yayıncılık.

Karadağ, Ö. (2012). Anlama becerileri açısından Türkçe dersi öğretim programına (6, 7, 8. sinıflar) eleştirel bir bakış. CÜ Sosyal Bilimler Dergisi, 36(1), 97-110.

Kıbrıs, S. (2019). Ortaokul (5-8. sınıflar) Türkçe dersi öğretim programı ve ders kitaplarında 'metin türü farkındalığı' (Yayınlanmamış yüksek lisans tezi). Başkent Üniversitesi.

Kurudayığlu, M. ve Soysal, T. (2019). 2018 Türkçe dersi öğretim programı kazanımlarının 21. yüzyıl becerileri açısından incelenmesi. Ahi Evran Üniversitesi Sosyal Bilimler Enstitüsü Dergisi, 5(2), 483-496.

Mason, L. H., Harris, K. R., ve Graham, S. (2011). Self-regulated strategy development for students with writing difficulties. Theory into practice, 50(1), 20- 27.

MEB (2006). Türkçe Dersi (İlkokul ve Ortaokul 1, 2, 3, 4, 5, 6, 7 ve 8. Sinıflar) Öğretim Programı, Ankara. Erişim adresi: http://mufredat.meb.gov.tr/Dosyalar/20065716392253-02T\%C3\%BCrk\%C3\%A7e\%20\%C3\%96\%C4\%9Fretim\%20Program\%C4\%B1\%202019.pdf

MEB (2015). Türkçe Dersi (ìlkokul ve Ortaokul 1, 2, 3, 4, 5, 6, 7 ve 8. Sinıflar) Öğretim Programı, Ankara. Erişim adresi: http://mufredat.meb.gov.tr/Dosyalar/20155716392253-02T\%C3\%BCrk\%C3\%A7e\%20\%C3\%96\%C4\%9Fretim\%20Program\%C4\%B1\%202019.pdf

MEB (2018). Türkçe Dersi (İlkokul ve Ortaokul 1, 2, 3, 4, 5, 6, 7 ve 8. Sinıflar) Öğretim Programı, Ankara. Erişim adresi: http://mufredat.meb.gov.tr/Dosyalar/20185716392253-02T\%C3\%BCrk\%C3\%A7e\%20\%C3\%96\%C4\%9Fretim\%20Program\%C4\%B1\%202019.pdf

MEB (2019). Türkçe Dersi (İlkokul ve Ortaokul 1, 2, 3, 4, 5, 6, 7 ve 8. Sinıflar) Öğretim Programı, Ankara. Erişim adresi: http://mufredat.meb.gov.tr/Dosyalar/20195716392253-02T\%C3\%BCrk\%C3\%A7e\%20\%C3\%96\%C4\%9Fretim\%20Program\%C4\%B1\%202019.pdf

Oxford, R. L. (1990). Language learning strategies: what every teacher should know. Newbury House Publishers.

Özdemir, E. ve Binyazar, A. (2006). Yazma öğretimi/yazma sanatı. Papirüs Yayınları.

Özdemir, E. (2008). Sözlü-yazılı anlatım sanatı kompozisyon. Remzi Kitabevi.

Sever, S. (2005). 2004 öğretim programında Türkçe öğretimi anlayışı. Eğitimde Yansımalar: VIII. Yeni İlköğretim Programlarını Değerlendirme Sempozyumu. 14-16 Kasım 2005. Kayseri: Erciyes Üniversitesi Yayınları, 177-192.

Söylemez, Y. (2018). 2018 Türkçe dersi öğretim programındaki kazanımların üst düzey düşünme becerileri açısından değerlendirilmesi. Türkiyat araştırmaları enstitüsü dergisi, 63, 345-384. Doi number: http://dx.doi.org/10.14222/Turkiyat3991 
Susar Kırmızı, F. ve Yurdakul, H. İ. (2019). Sınıf öğretmenlerinin 2018 Türkçe dersi öğretim programına ilişkin görüşleri. Ĕgitim Kuram ve Uygulama Araştırmaları Dergisi, 5(1), 6476.

Şahin, D. ve Bayramoğlu, C. D. (2016). 2015 Türkçe öğretim programının metin tür ve tema seçimi bakımından değerlendirilmesi. Turkish Studies, 11(3), 2095-2130. http://dx.doi.org/10.7827/TurkishStudies.9289

Tompkins, G. E. (2000). Teaching writing: balancing product and process. Merrill/PrenticeHall.

Topuzkanamış, E. (2014). Yazma stratejileri öğretiminin Türkçe öğretmenliği birinci sınıf öğrencilerinin yazma başarısına etkisi. Uluslararası Türkçe Edebiyat Kültür Eğitim Dergisi, 3(2), 274-290.

Türkiye Yeterlilikler Veri Tabanı (2019). Türkiye yeterlilikler çerçevesi. Erişim Adresi: http://portal.tyc.gov.tr/.

Yıldırım, A. ve Şimşek, H. (2015). Sosyal bilimlerde nitel araştırma yöntemleri. Seçkin Yayıncılık.

Yılmaz, D. ve Turan, H. (2019). Dijital hikâye anlatımı ve 2018 türkçe dersi öğretim programının karşılaştırılması, Turkish Studies-Educational Sciencies, 14(3), 949-962. http://dx.doi.org/10.29228/TurkishStudies.22662 